\section{Cureus}

\title{
Fludrocortisone Replacement in Unawake Selected Neurosurgical Patients
}

\author{
Sunil Munakomi ${ }^{1}$, Binod Bhattarai ${ }^{2}$, Iype Cherian ${ }^{1}$, Balaji Srinivas ${ }^{3}$ \\ 1. Neurological Surgery, Nobel Medical College and Teaching Hospital, Biratnagar, NPL 2. Neurosurgery, \\ College of Medical Sciences, Bharatpur, Nepal, Bharatpur, NPL 3. Neurosurgery, College of Medical \\ Sciences, Bharatpur, Nepal
}

$\square$ Corresponding author: Sunil Munakomi, sunilmunakomi@gmail.com Disclosures can be found in Additional Information at the end of the article

\section{Abstract}

Critical illness-related cortisol insufficiency is a known entity. However, there are instances where there is a normal serum cortisol level in an unresponsive patient with low Glasgow Coma Scale (GCS), even after thorough investigations to rule out other correctable entities. In patients with lesions in the vicinity of hypothalamus, especially basifrontal contusion and vascular lesions affecting anterior communicating artery (ACOM) territory, we propose to see the efficacy of fludrocortisone replacement on such patients.

Categories: Emergency Medicine, Neurosurgery

Keywords: cortisol insufficiency, fludrocortisone, replacement

\section{Introduction}

Traumatic brain injury is an important public health issue that requires the expertise of informed neurosurgeons, neurointensivists, and other critical care practitioners [1]. Electrolyte abnormalities are common in patients with head injuries, occurring at least once during the hospital course of $59 \%$ of the traumatic coma data bank (TCDB) patients and disturbances in serum sodium level, both hyponatremia and hypernatremia, are among the most common [2]. Meticulous attention should be paid to fluid administration and fluid balance [3]. Serum sodium disturbances frequently occur in neurosurgical and neurologic patients and exacerbate their neurologic and general conditions. The disturbance may manifest as hypernatremia or hyponatremia. Hypernatremia usually occurs in the diabetes insipidus syndrome, whereas hyponatremia develops as a syndrome of systemic inappropriate antidiuretic hormone (SIADH) secretion or cerebral salt-wasting syndrome (CSWS), and contribute to the high morbidity and mortality rates observed in these patients [4-6].

Received 11/07/2014

Review began 11/08/2014 Review ended 11/11/2014 Published 11/11/2014

\section{(C) Copyright 2014}

Munakomi et al. This is an open access article distributed under the terms of the Creative Commons Attribution License CC-BY 3.0., which permits unrestricted use, distribution, and reproduction in any medium, provided the original author and source are credited.

\section{Materials And Methods}

We included five patients in our study after ruling out surgically correctable causes as well as dyselectrolytemia. Tab fludrocortisone was prescribed starting with the dose of $0.1 \mathrm{mg}$ bd to a maximum of $0.5 \mathrm{mg}$ bd. Patients were monitored for features of dyselectrolytemia as well as pulmonary odema. Time to improvement was assessed in number of days in terms of the Glasgow coma scale (GCS).

Our study was approved by the Ethical Committee of the College of Medical Sciences. Written consents were taken from the patient parties. 


\section{Cureus}

\section{Results}

There was improvement with GCS score of at least two (earliest improvement in eye [E] component) within two to three days of the initiation of fludrocortisone replacement therapy. Replacement was done within seven to 10 days of admission after ruling out surgically correctable pathologies or other dyselectrolytemias. All patients had good Glasgow outcome scores (GOS) at one month follow-up (Table 1).

\begin{tabular}{|c|c|c|c|c|c|c|}
\hline S.NO & Diagnosis & $\begin{array}{l}\text { Day of initiation of } \\
\text { replacement }\end{array}$ & $\begin{array}{l}\text { Initial } \\
\text { GCS }\end{array}$ & $\begin{array}{l}\text { Days to } \\
\text { improvement }\end{array}$ & $\begin{array}{l}\text { GCS at } \\
\text { discharge }\end{array}$ & $\begin{array}{l}\text { GOS at } 1 \text { month } \\
\text { follow Up }\end{array}$ \\
\hline 1 & $\begin{array}{l}\text { Bilateral basifrontal } \\
\text { contusion }\end{array}$ & 7 & E2M4V2 & 3 & E4M5V4 & 4 \\
\hline 2 & $\begin{array}{l}\text { Bilateral basifrontal } \\
\text { contusion }\end{array}$ & 8 & E3M5V3 & 3 & E4M6V5 & 5 \\
\hline 3 & $\begin{array}{l}\text { Ruptured ACOM } \\
\text { aneurysm }\end{array}$ & 7 & E2M5V3 & 2 & E4M5V4 & 4 \\
\hline 4 & $\begin{array}{l}\text { Ruptured ACOM } \\
\text { aneurysm }\end{array}$ & 9 & E3M4V3 & 3 & E4M5V4 & 4 \\
\hline 5 & Hypoxic brain injury & 9 & E2M4V3 & 3 & E4M5V4 & 4 \\
\hline
\end{tabular}

\section{TABLE 1: Profile of the patients included in the study}

\section{Case 1}

A 32-year-old female, a case of a road traffic accident (RTA) with GCS of 15/15, had bifrontal multiple scattered contusions with no mass effect in the CT scan. She was managed conservatively. On the sixth postoperative day, there was deterioration in the GCS of the patient to E2M4V2. Repeat CT showed perilesional odema. She had normal urine output, normal serum sodium, and cortisol level. She was started on fludrocortisone with $0.1 \mathrm{mg}$ bd. Her GCS improved to E4M5V4 on the third day of initiation of the replacement. She was subsequently referred to the plastic surgery department for the management of a decubitus ulcer in the sacral region. She followed up one month later with a GCS of 15 and GOS of 5.

\section{Case 2}

A 60-year-old male presented with sudden onset headache, multiple episodes of vomiting, and altered sensorium of one day's duration. CT scan showed a subarachnoid hemorrhage (SAH) Fisher Grade 4 with ventricular extension. Angiography revealed medially pointing left A1 dominant ACOM aneurysm.

He underwent a left pterional craniotomy and clipping of left A1 dominant ACOM aneurysm and incidental left posterior communicating artery (PCOM) aneurysm. Postoperative scan showed left basifrontal contusion with no mass effect. The GCS was persistently E2M5V3. The serum cortisol and electrolytes were within normal range. He was started on fludrocortisones replacement. The GCS improved to E4M5V4 on the second day. The GOS at one month followup was four. 


\section{Discussion}

Critical illness-related corticosteroid insufficiency (CIRCI) reaches up to 50 to $70 \%$ of trauma patients [8-10]. CIRCI increases systemic inflammation and vasopressive requirement [8, 11]. Hydrocortisone decreases the rate of hospital-acquired pneumonia (HAP) and duration of mechanical ventilation in multiple trauma patients with CIRCI [9]. In a subgroup analysis of the HYPOLYTE (Hydrocortisone Polytraumatise) trial, hydrocortisone appears particularly efficient in multiple trauma patients with traumatic brain injury (TBI) [9].

Fludrocortisone was proposed in association with hydrocortisone for the treatment of CIRCI in septic patients [12] and is recommended in brain injury patients with spontaneous subarachnoid hemorrhage who experience hyponatremia [13].

The timing of mineralocorticoid deficiency (MD) onset is important in evaluating the possible mechanism for MD. One proposed cause of MD is enhanced $17 \alpha$-hydroxylase expression, which is seen after chronic stress in rats and in cultured bovine zona glomerulosa cells chronically exposed to adrenocorticotrophic hormone (ACTH) [14-15]. In animal studies, mild hemorrhage and hypotension resulted in adrenal necrosis within four hours and was associated with a significant decrease in serum glucocorticoid levels [16]. Hypotension and hypoxia may also contribute to the development of MD through release of reactive oxygen species (ROS), cytokines, and dopamine-all of which inhibit aldosterone synthase [17-19]. No data regarding fludrocortisones use in TBI patients are available to date.

\section{Conclusions}

Replacement with fludrocortisone can have a beneficial effect on the clinical improvement of patients with traumatic and vascular insult surrounding hypothalamus territory who remain unawake with low GCS for a prolonged time (7-10 days) without any evidence of dyselectrolytemia or any surgically correctable lesions, especially for lesions near the third ventricle. It is advisable to rule out hypocortisolism, cerebral salt wasting, SIADH, and surgically corrected mass lesion before initiation of the replacement therapy. Further confirmation can be validated by inclusion of a large number of patients.

\section{Additional Information \\ Disclosures}

Human subjects: Consent was obtained by all participants in this study. Ethical Committee of the College of Medical Sciences issued approval N/A. In Nepal, we do not have the protocol numbering system. We present the study to the Ethical Committee and if reasonable, they approve it. Animal subjects: All authors have confirmed that this study did not involve animal subjects or tissue. Conflicts of interest: In compliance with the ICMJE uniform disclosure form, all authors declare the following: Payment/services info: All authors have declared that no financial support was received from any organization for the submitted work. Financial relationships: All authors have declared that they have no financial relationships at present or within the previous three years with any organizations that might have an interest in the submitted work. Other relationships: All authors have declared that there are no other relationships or activities that could appear to have influenced the submitted work.

\section{References}

1. Vespa P: Cerebral salt wasting after traumatic brain injury: An important critical care treatment issue. Surg Neurol. 2008, 69:230-2. 10.1016/j.surneu.2007.02.050

2. Piek J, Chesnut RM, Marshall LF, van Berkum-Clark M, Klauber MR, Blunt BA, Eisenberg HM, Jane JA, Marmarou A, Foulkes MA: Extracranial complications of severe head injury . J 
Neurosurg. 1992, 77:901-7.

3. Robertson C: Critical care management of traumatic brain injury . Youmans Neurological Surgery. Winn HR, Youmans JR (ed): Saunders, Philadelphia; 2004. Vol. 4:5103-5144.

4. Blevins LS Jr, Wand GS: Diabetes insipidus. Crit Care Med. 1992, 20:69-79.

5. Dóczi T, Bende J, Huszka E, Kiss J: Syndrome of inappropriate secretion of antidiuretic hormone after subarachnoid hemorrhage. Neurosurg. 1981, 9:394-7.

6. Harrigan MR: Cerebral salt wasting syndrome. Crit Care Clin. 2001, 17:125-38.

7. Cintra Ede A, Araújo S, Quagliato EM, Castro Md, Falcão AL, Dragosavac D, Terzi RG: Vasopressin serum levels and disorders of sodium and water balance in patients with severe brain injury. Arq Neuropsiquiatr. 2007, 65:1158-65.

8. Hoen S, Asehnoune K, Brailly-Tabard S, Mazoit JX, Benhamou D, Moine P, Edouard AR: Cortisol response to corticotropin stimulation in trauma patients: Influence of hemorrhagic shock. Anesthesiology. 2002, 97:807-13.

9. Roquilly A, Mahe PJ, Seguin P, Guitton C, Floch H, Tellier AC, Merson L, Renard B, Malledant Y, Flet L, Sebille V, Volteau C, Masson D, Nguyen JM, Lejus C, Asehnoune K: Hydrocortisone therapy for patients with multiple trauma: The randomized controlled HYPOLYTE study. JAMA. 2011, 305:1201-9. 10.1001/jama.2011.360

10. Cohan P, Wang C, McArthur DL, Cook SW, Dusick JR, Armin B, Swerdloff R, Vespa P, Muizelaar JP, Cryer HG, Christenson PD, Kelly DF: Acute secondary adrenal insufficiency after traumatic brain injury: A prospective study. Crit Care Med. 2005, 33:2358-66.

11. Woiciechowsky C, Schöning B, Lanksch WR, Volk HD, Döcke WD: Mechanisms of brainmediated systemic anti-inflammatory syndrome causing immunodepression. J Mol Med (Berl). 1999, 77:769-80.

12. Annane D, Sébille V, Charpentier C, Bollaert PE, François B, Korach JM, Capellier G, Cohen Y, Azoulay E, Troché G, Chaumet-Riffaud P, Bellissant E: Effect of treatment with low doses of hydrocortisone and fludrocortisone on mortality in patients with septic shock. JAMA. 2002, 288:862-71.

13. Bederson JB, Connolly ES Jr, Batjer HH, Dacey RG, Dion JE, Diringer MN, Duldner JE Jr, Harbaugh RE, Patel AB, Rosenwasser RH; American Heart Association: Guidelines for the management of aneurysmal subarachnoid hemorrhage: a statement for healthcare professionals from a special writing group of the Stroke Council, American Heart Association. Stroke. 2009, 40:994-1025. 10.1161/STROKEAHA.108.191395

14. Aguilera G, Kiss A, Sunar-Akbasak B: Hyperreninemic hypoaldosteronism after chronic stress in the rat. J Clin Invest. 1995, 96:1512-9.

15. Braley LM, Adler GK, Mortensen RM, Conlin PR, Chen R, Hallahan J, Menachery AI, Williams $\mathrm{GH}$ : Dose effect of adrenocorticotropin on aldosterone and cortisol biosynthesis in cultured bovine adrenal glomerulosa cells: In vitro correlate of hyperreninemic hypoaldosteronism. Endocrinology. 1992, 131:187-94.

16. Hollenberg SM, Ahrens TS, Annane D, Astiz ME, Chalfin DB, Dasta JF, Heard SO, Martin C, Napolitano LM, Susla GM, Totaro R, Vincent JL, Zanotti-Cavazzoni S: Practice parameters for hemodynamic support of sepsis in adult patients: 2004 update. Crit Care Med. 2004, 32:192848.

17. Crivello JF, Hornsby PJ, Gill GN: Metyrapone and antioxidants are required to maintain aldosterone synthesis by cultured bovine adrenocortical zona glomerulosa cells. Endocrinology. 1982, 111:469-79.

18. Aguilera G, Catt KJ: Dopaminergic modulation of aldosterone secretion in the rat . Endocrinology. 1984, 114:176-81.

19. Natarajan R, Ploszaj S, Horton R, Nadler J: Tumor necrosis factor and interleukin-1 are potent inhibitors of angiotensin-II-induced aldosterone synthesis. Endocrinology. 1989, 125:3084-9. 